\title{
SELF-ORGANIZED CRITICALITY IN EVOLUTION OF NUCLEAR FUEL MICROSTRUCTURE*
}

\author{
I. Petrashenko, L. Juodis, G. Trinkūnas, and V. Remeikis \\ Institute of Physics, Savanoriu 231, LT-02300 Vilnius, Lithuania \\ E-mail: laurynas@ar.fi.lt
}

Received 2 June 2005

\begin{abstract}
Nuclear fuel microstructure has major influence on the fission product release from nuclear fuel matrix. Here we present the self-organized criticality model applied to describe the evolution of nuclear fuel microstructure. It is shown that the behaviour of fuel bubbles is similar to that of species in natural ecosystems and their evolution can be characterized as an avalanche process. Modelled bubble size distribution for different fuel burnups is in good agreement with the experimental data.
\end{abstract}

Keywords: nuclear fuel, structure, self-organized criticality, modelling

PACS: 28.41.Bm, 05.65, 61.43.Bn

\section{Introduction}

Analysis and determination of fission products (FP) release from nuclear fuel evolved into a certain field of applied nuclear and theoretical physics. Nuclear fuel is a unique system where complex processes of fission of nuclei by neutrons, release of heat, accumulation, and migration of FP occur. The latter process is a particularly important nuclear engineering issue - it determines the lifetime of nuclear fuel in a reactor, i. e., its maximum allowable burnup. There is a natural need to extend maximum burnup of nuclear fuel in order to minimize amounts of radioactive waste and to improve efficiency of nuclear facilities. Studies of nuclear fuel behaviour over several decades revealed essential influence of nuclear fuel microstructure on fuel characteristics [1,2]. One of crucial issues limiting nuclear fuel lifetime is the change of its characteristics due to evolution of fuel matrix structure. Fission of uranium nuclei composing the fuel matrix results in accumulated FP and reduced thermal conductivity, swelling of fuel pellets, and fuel-clad mechanical interaction due to volume increase, giving rise to potential hazard to the fuel cladding damage. Different conceptual approaches to describe the fuel microstructure by classical Booth [1] or newer methods, such as cellular automata [2] or fractals [3], and computer codes [4-6 and references therein] have been developed for modelling

\footnotetext{
* The report presented at the 36th Lithuanian National Physics Conference, 16-18 June 2005, Vilnius, Lithuania.
}

the FP release taking into account various fuel parameters as well as various experimental methods applied to test the mathematical models. In this paper we apply a new theoretical model to predict the nuclear fuel microstructure during its burnup in the nuclear reactor.

\section{Nuclear fuel structure evolution}

Nuclear fuel is a nonhomogeneous material from the very beginning after its sintering process. It is a polycrystalline material composed of small $(\sim 10 \mu \mathrm{m})$ grains which are $\mathrm{UO}_{2}$ crystals. Grain boundaries are formed between the grains and they play important role in FP release [6]. Both in grains and grain boundaries the intra-granular and inter-granular FP bubbles are formed in the course of fuel burnup.

Fresh nuclear fuel is therefore a polycrystalline material with heterogeneous structure that changes during the burnup process in a reactor. During the fuel irradiation FP are generated in the whole volume of fuel pellets. Some of FP, especially noble gases such as $\mathrm{Kr}$, $\mathrm{Xe}$, are generated to sufficient concentrations and due to very low solubility in $\mathrm{UO}_{2}$ matrix tend to precipitate into small intra-granular bubbles [7]. These intragranular bubbles act as traps for migrating FP and thus hinder their diffusion to grain boundaries [7,8]. It has been realized that the increasing porosity of the fuel with the burnup has direct influence on the FP release $[6,7]$. 
Individual intra-granular bubbles, however, are very unstable due to their resolution by irradiation. Their size distribution and concentration in grains are determined by the local fuel temperature and fission rate (diameter $\sim 1-10 \mathrm{~nm}$, density $10^{17} \mathrm{~cm}^{-3}$ ). In various experiments it has been observed that intra-granular bubbles are formed in straight lines $[8,9]$, which are believed to be the tracks of fission fragments generated by the fission of uranium nuclei [10]. Further, small bubbles can be destroyed by fission fragments [11]. At higher burnups intra-granular bubble size distribution changes and bigger bubbles of 20-100 nm size with $10^{15} \mathrm{~cm}^{-3}$ density occur, which are often identified at matrix dislocations. At higher temperatures completely bubble-free intra-granular areas exist. Therefore, the bubble coarsening process with increasing burnup occurs $[8,9]$.

In [7] it is noted that a model for bubble size distribution could be useful for the prediction of the FP release. However, difficulties occurred while describing the influence of the fuel structure on the FP release by means of an intragranular bubble growth process [2]. In this paper we present a qualitatively new approach to describe the structure of the nuclear fuel and to determine its new fundamental characteristics. In particular, we suggest that the structure of the nuclear fuel follows similar rules observed in the real biological evolution in nature.

\section{Analogy between nuclear fuel and biological evolution}

The nuclear fuel structure evolution is to some extent a process similar to interaction of species in nature. There have been attempts to describe the structure of nuclear fuel applying the laws of Game of Life [3], invented by John Conway. The evolution of the nuclear fuel structure can be viewed as a process following some simple local rules. This is observed in a form of interaction of the fuel matrix with the FP bubbles. Here we draw a parallel between the nuclear fuel and biological evolution in order to determine fundamental processes of nuclear fuel evolution during burnup. Bak and Sneppen in [12] established the model describing the biological evolution in terms of self-organized criticality. In this model the system is composed of a chain of species characterized by some parameter representing their fitness. This parameter can change (mutate) when it is poorly adapted to the environment.

Here we try to find some analogy between the biological species and nuclear fuel bubbles experienc-

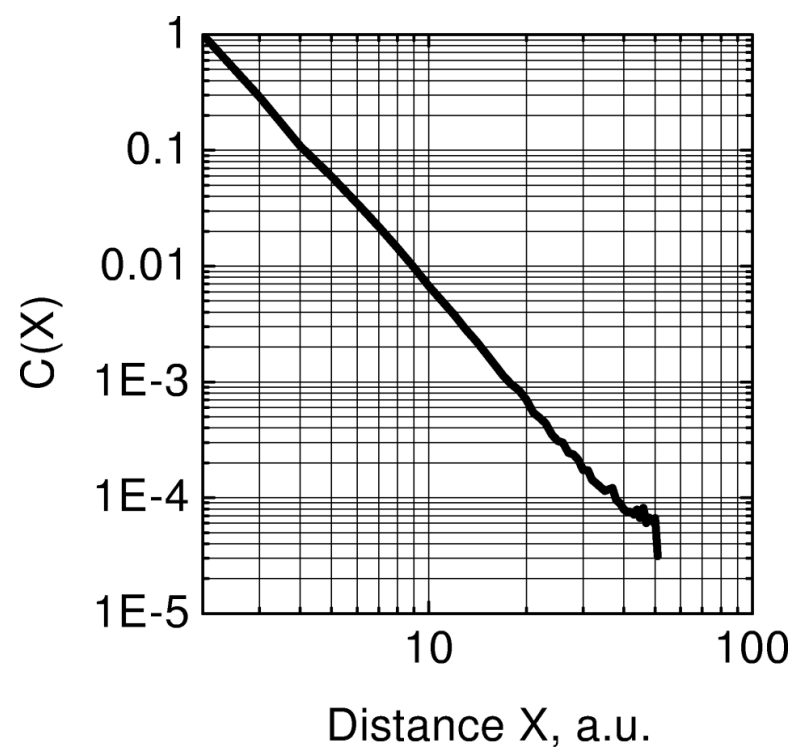

Fig. 1. Normalized number of occurrences $C(X)$ of distances $X$ between successive mutations of bubbles corresponding to the 16.2 MWd/kgU burnup.

ing the change of temperature, irradiation, hydrostatic pressure, etc. during fuel burnup. We model the fuel structure representing it as a chain of fuel bubbles having different sizes. The biggest bubble has the highest probability to change as it can simply be destroyed by a fission fragment. Then FP of the destroyed bubble can be redistributed to the neighbour bubbles.

The fuel structure is described as a 1D chain of bubbles following the radial bubble distribution in a fuel pellet from the centre to its boundary. Each bubble is characterized by a random measure $B_{i} \quad(i=$

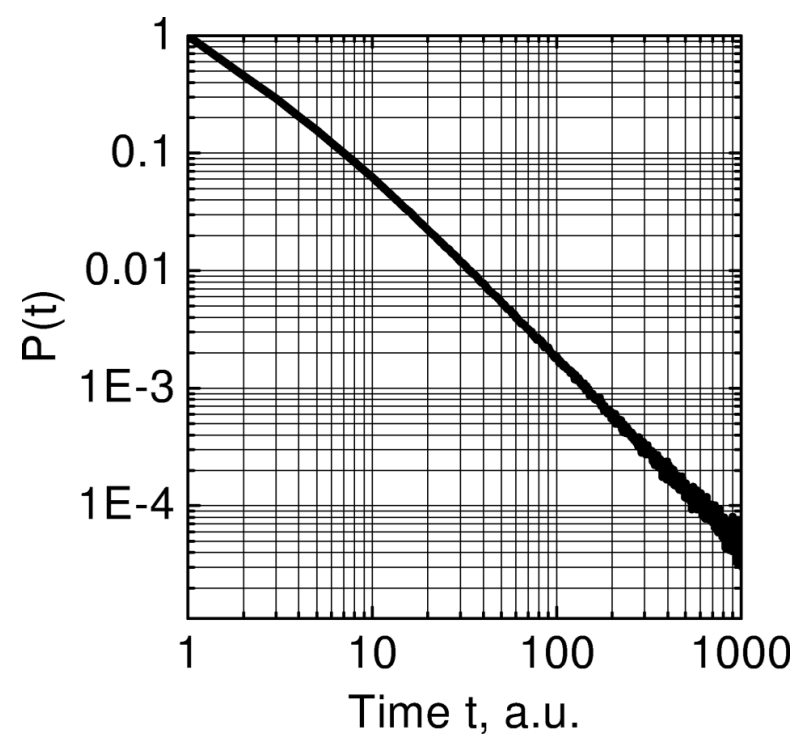

Fig. 2. Normalized number of occurrences $P(t)$ of time periods $t$ between mutations of each bubble (stasis time distribution) corresponding to the $16.2 \mathrm{MWd} / \mathrm{kgU}$ burnup. 

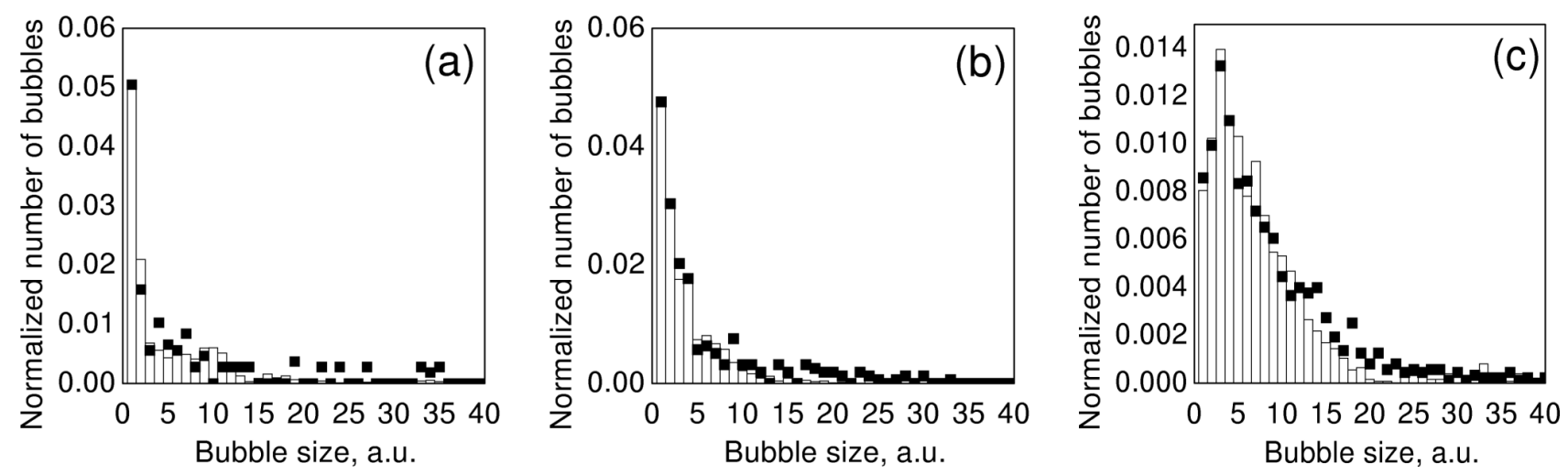

Fig. 3. Bubble size distributions for (a) $16.2 \mathrm{MWd} / \mathrm{kgU}$, (b) $42.6 \mathrm{MWd} / \mathrm{kgU}$, and (c) $65,0 \mathrm{MWd} / \mathrm{kgU}$ burnups. Bars stand for the experimental histograms [3] and solid squares are for the simulated data.

$1, \ldots, N)$ from the $\{0,100\}$ interval. The latter can be associated with the bubble radius. Then, during simulation, a bubble with the maximal radius $B_{i}$ is found and this value is changed to a new random value from the interval $\{0,100\}$ along with the radii $B_{i-1}$ and $B_{i+1}$ of neighbour bubbles that are also changed at random. This process is iterated until a steady state in the chain of bubbles is achieved.

The steady state for a chain of 100 bubbles is characterized by some critical measure, which depends on the degree of the interaction between the mutating and neighbour bubbles. In order to model different fuel burnup structures we considered the following cases:

(a) Mutation of the critical bubble and one randomly selected neighbour bubble with redistribution of the critical bubble gas to mutated neighbours.

(b) The same as (a) but involving both neighbours.

(c) The same as (a) but involving five nearest neighbour bubbles and redistributing gas at random.

\section{Model results}

Table 1 summarizes the results of modelling. Distributions of distances between successive bubble changes

Table 1. Model parameters corresponding to the three fuel burnup cases. $B_{\text {cr }}$ is the critical value of bubble size, $C(X)$ and $P(t)$ are the normalized number of occurrences of distance between mutating bubbles and time for a certain bubble.

\begin{tabular}{lccc}
\hline Model & \multicolumn{3}{c}{ Case } \\
\cline { 2 - 4 } parameters & (a) & (b) & (c) \\
\hline$B_{\mathrm{cr}}$ & $44 \pm 1$ & $48 \pm 1$ & $67 \pm 1$ \\
$C(X)$ & $X^{-3.0 \pm 0.01}$ & $X^{-2.9 \pm 0.01}$ & $X^{-2.7 \pm 0.01}$ \\
$P(t)$ & $t^{-1.55 \pm 0.01}$ & $t^{-1.51 \pm 0.01}$ & $t^{-1.4 \pm 0.01}$ \\
Fuel burnup, & & & \\
MWd/kgU & 16.2 & 42.6 & 65.0 \\
\hline
\end{tabular}

as well as the time between successive mutations in each and every bubble are well described by power laws. This proves that the system is in a critical state [12]. As this state does not depend on initial conditions, the system is self-organized. The changes in such a bubble chain representing the radial nuclear fuel pellet structure are an avalanche process. For a long period of time an individual bubble is passive, then it can undergo sudden bursts of activity, which can be explained as an interaction of a bubble with its environment: resolution by a fission fragment, change of volume due to hydrostatic pressure, and trapping or release of FP. Distributions of distances $X$ between successive mutations $C(X)$ and that of time periods $t$ between mutations of each and every bubble $P(t)$ evaluated for the lowest burnup case are presented in Figs. 1 and 2, respectively. These distributions are characteristic of the selforganized critical system, which does not have characteristic spatial and time scales and the system evolves by means of avalanche processes [12].

The above presented mutation rules, namely the number of involved bubbles neighbouring the critical one, were adjusted to fit the experimental data of bubble size distributions for three different fuel burnups. Model statistics of the bubble sizes presented in Fig. 3 well resemble the histograms obtained from fuel section micrograms [3] and therefore support the model of self-organized criticality of the FP bubble evolution.

\section{Conclusions}

A 1D model of the FP bubble size evolution in nuclear fuel has been developed. It is shown that the model of the nuclear fuel microstructure reaches the self-organized critical state with characteristic parameters. The FP bubbles change during the fuel burnup by means of avalanche processes: the long periods of 
individual bubbles being at rest are succeeded by the sudden bursts of activity. This model well describes the FP bubble size distribution in a fuel matrix and suggests that higher burnups could be related to better developed bubble connectivity when a larger number of neighbour bubbles is involved in the event of the critical bubble change.

\section{Acknowledgement}

This work was supported by the Lithuanian State Science and Studies Foundation under the project No. C-19/2003.

\section{References}

[1] A.H. Booth, A suggested method for calculating the diffusion of radioactive rare gas fission products from $\mathrm{UO}_{2}$ fuel elements and a discussion of proposed inreactor experiments that may be used to test its validity, Report DCI-27, September 1957, Atomic Energy of Canada Ltd. Chalk River Project, Chalk River, Ontario.

[2] R.J. White, The fractal nature of the surface of uranium dioxide: A resolution of the short-lived/stable gas release dichotomy, J. Nucl. Mater. 295, 133-148 (2001).

[3] I. Antoniou, E.P. Akishina, V.V. Ivanov, B.F. Kostenko, and A.D. Stalios, Cellular automata study of high bur- nup structures, Chaos, Solitons and Fractals 18, 11111128 (2003).

[4] K. Lassmann and H. Benk, Numerical algorithms for intragranular fission gas release, J. Nucl. Mater. 280, $127-135$ (2000).

[5] L.O. Jernkvist, A.R. Massih, and J. In de Betou, Evaluation of fission product gas release and the impact of fuel microstructure at high burnup, Paper presented at the Enlarged Halden Programme Group Meeting, September 8-13, 2002, Storefjell, Gol, Norway.

[6] D.R. Olander and P. van Uffelen, On the role of grain boundary diffusion in fission gas release, J. Nucl. Mater. 228, 137-147 (2001).

[7] P. Lösönen, On the behaviour of intragranular fission gas in $\mathrm{UO}_{2}$ fuel, J. Nucl. Mater. 280, 56-72 (2000).

[8] C. Baker, The migration of intragranular fission gas bubbles in irradiated uranium dioxide, J. Nucl. Mater. 71, 117-123 (1977).

[9] J.A. Turnbull, The distribution of intragranular fission gas bubbles in $\mathrm{UO}_{2}$ during irradiation, J. Nucl. Mater. 38, 203-212 (1971).

[10] M.E. Gulden, Migration of gas bubbles in irradiated uranium dioxide, J. Nucl. Mater. 23, 30-36 (1967).

[11] G.J. Small, The elimination of small voids in $\mathrm{UO}_{2}$ during irradiation, J. Nucl. Mater. 125, 117-119 (1984).

[12] P. Bak and K. Sneppen, Punctuated equilibrium and criticality in a simple model of evolution, Phys. Rev. Lett. 71, 4083-4086 (1993).

\title{
SAVIORGANIZUOTAS KRITIŠKUMAS BRANDUOLINIO KURO MIKROSTRŪKTROS EVOLIUCIJOJE
}

\author{
I. Petrashenko, L. Juodis, G. Trinkūnas, V. Remeikis
}

Fizikos institutas, Vilnius, Lietuva

\section{Santrauka}

Branduolinio kuro (BK) dalijimosi produktu (DP) migraciją stipriai ittakoja $\mathrm{BK}$ tablečių $\mathrm{UO}_{2}$ polikristalinès struktūros kaita degimo proceso metu - ertmiu su DP susidarymas ir išnykimas. Šiame darbe, modeliuojant BK mikrostruktūros evoliuciją reaktoriuje, pritaikytas biologiniu ekosistemų evoliucijos saviorganizuoto kritiškumo modelis. Iškelta hipotezè, kad reaktoriuje išdegančio $\mathrm{BK}$ dariniai - ertmès su DP - sąveikaudamos su $\mathrm{UO}_{2}$ matrica ir dèl radiacinio poveikio taip pat patenka ị saviorganizuotą būseną.

BK ertmes aprašème vienmate grandinèle su periodinèmis kraštinemis sąlygomis. Kiekvienai iš ertmiu priskyrème jos dydi apibūdinantị parametrą $B_{i}$. Kritinius ịvykius modeliavome, didžiausios ertmès ir jos kaimynu parametrus keisdami atsitiktinèmis ver- tėmis. Nustatyta, kad po tam tikro ciklų skaičiaus nusistovi būsena, kuri apibūdinama atstumų tarp paeiliui i̇vykusiu pokyčiu laipsniniu skirstiniu su laipsnio rodikliu, būdingu modeliuojamai sistemai. Toks skirstinys rodo, kad sistema yra saviorganizuotos kritinès būsenos, kurios pokyčiai vyksta griūtimis: atskira ertmė ilgą laikotarpi gali būti pasyvi, tačiau staiga gali patirti aktyvumo proverži, paaiškinamą ertmès sąveika su aplinka - jos sunaikinimą dalijimosi skeveldra, tūrio pokyti dèl hidrostatinio slègio ar DP pagavimo. Modeliuojant pastebèta, kad gretimai kintančių ertmių skaičius lemia ertmès dydžio pasiskirstymo pavidalą. Palyginus modelinius ertmių dydžiu skirstinius su eksperimentiniais, gretimų ertmių, dalyvaujančių kritiniame ivvykyje, skaičius susietas su BK išdegimo laipsniu. 